\title{
Successful Intravenous Lipid Infusion Therapy in a Case with Life-Threatening Calcium Channel and Beta Blockers Overdose
}

\author{
Hayatı Tehdit Eden Kalsiyum Kanal Blokeri ve Beta Bloker Zehirlenme Olgusunda Başarıı \\ Intravenöz Lipit Infüzyon Tedavisi
}

\author{
Fatih Durak1, Fulya Kamit Can1, Neslihan Zengin1, Ikbal Durak2, Kerem Yıldız'1, Ayşe Berna Anıl3 \\ 1izmir Tepecik Training and Research Hospital, Clinic of Pediatric Intensive Care, Izmir, Turkey \\ 2 Izmir Egepol Hospital, Clinic of Pediatric, Izmir, Turkey \\ 3izmir Katip Çelebi University Faculty of Medicine, Division of Pediatric Intensive Care, Izmir, Turkey
}

\section{Abstract}

Life-threatening cardiovascular collapse symptoms can develop due to calcium channel and beta-receptor blocker poisoning and there are no specific antidotes for treatment.

A 13-year-old girl was admitted with severe hypotension and bradycardia after the ingestion of a large quantity of carvedilol and verapamil. Cardiovascular collapse was resistant to fluid therapy, calcium gluconat and high-dose vasopressor infusion. Intravenous lipid infusion was administered in the patient who had resistant hypotension with hipereinsulinemic euglycemia on the first hour of hospitalization. Hemodynamic stability of the patient was achieved 30 minutes after lipid administration. Calcium channel and betareceptor blocker overdose may result in life-threatening intoxication. Classical therapies that are suggested for these intoxications can be insufficient. Favorable results can be obtained after intravenous lipid infusion. With this report, we aimed to draw attention to those intoxications that can be life-threatening and to emphasize that intravenous lipid infusion therapy can be successful in patients refractory to other treatments.

Keywords: Intoxication, calcium channel blocker, beta receptor blocker, hyperinsulinemic euglycemia, intravenous lipid infusion

\section{Öz}

Kalsiyum kanal ve beta reseptör blokerleri ile olan zehirlenmelerde hayatı tehdit edici kardiyovasküler kollaps bulguları gelişebilmekte ve tedavi için özgül bir antidot bulunmamaktadır.

On üç yaşında kız olgu, aşırı doz karvedilol ve verapamil alımını takiben ciddi hipotansiyon ve bradikardi bulguları ile getirildi. Kardiyovasküler kollaps tablosu sıvı tedavisi, kalsiyum glukonat ve yüksek doz vasopressör infüzyonuna dirençli idi. Hiperinsülinemik öglisemi tedavisi ile de dirençli hipotansiyonu devam eden olguya intravenöz lipit infüzyonu izleminin 1. saatinde uygulandı. Olgunun hemodinamik stabilitesi lipit uygulamasından yarım saat sonra sağlandı. Kalsiyum kanal ve beta reseptör blokerleri ile olan zehirlenmeler, hayatı tehdit edebilen zehirlenmelerdir. Bu zehirlenmelerde önerilen klasik destek tedavileri yetersiz kalabilmekte, intravenöz lipit infüzyonu ile başarılı sonuçlar alınabilmektedir. Biz de bu olgu ile hayati tehlike yaratabilen bu zehirlenmelere tekrar dikkat çekmek ve diğer tedavilere yanıtsız olgularda intravenöz lipit infüzyonu tedavisinin başarılı olabileceğini vurgulamak istedik.

Anahtar Kelimeler: Zehirlenme, kalsiyum kanal blokeri, beta reseptör blokeri, hiperinsülinemik öglisemi, intravenöz lipit infüzyonu

\section{Introduction}

Calcium channel blocker (CCB) and $\beta$ receptor blocker (BB) overdoses constitute a small percentage among all intoxications. ${ }^{1}$ According to the 2014 Annual Report of the American Association of Poison Control Center's National Poison Data System, $0.6 \%$ of all overdoses occur with CCB and $0.9 \%$ take place with BB. 2 However, these overdoses lead to severe toxicity and their mortality rates are quite high. 3 BB drugs cause hypotension and bradycardia by attaching to the beta adrenoceptors. ${ }^{4}$ In some BB overdoses, however, since the drug has lipid resolution, central nervous system findings (such as seizure, respiratory depression, coma) can be observed. 4 Following the excessive intake of CCB and BB drugs, treatments, such as glucagon, calcium gluconate, and hyperinsulinemic euglycemia therapy (HIET) as well as vasopressor drugs and intravenous fluid therapy are used in cases with cardiovascular collapse. 5 Lately, in CCB and BB poisonings unresponsive to standard therapy, Recently, intravenous lipid infusion (ILI) therapy, which is used for poisoning with lipophilic local anesthetics and chemical 
agents, is a new therapy option when the standard therapy is inefective for poisoning with CCB and BB intoxications. ${ }^{5} \mathrm{~A}$ variety of theories have been suggested on the mechanism of action of ILI. According to the "lipid-sink theory"; ILI holds the lipophilic drugs where by forming a separate compartment in plasma and reduces the unwanted side effects of these drugs. Meanwhile, it also decreases toxic effects by drawing drugs that entered into cells to the extracellular field; namely, plasma. Free fatty acids contribute to inotropic effect by providing energy substrate to depressed myocardium. 6 In addition, in myocardium with poor contractility, ILI administration has been claimed to cause positive inotropic and chronotropic effects by ameliorating functions of ion channels (like sodium and calcium) located on cell membranes. ${ }^{7}$

In this paper, we aimed to emphasize the effectiveness of ILI therapy in a pediatric patient who developed severe cardiovascular toxicity following high-dose BB and CCB drugs resistant to standard therapies.

\section{Case}

A 13-year-old girl was brought to our hospital due to intake of unknown amount of carvedilol and verapamil in a suicide attempt. Gastric lavage was performed in the primary care center after two hours of drug intake. At the same center she was conscious and she was given $1 \mathrm{~g} / \mathrm{kg}$ of oral activated coal. The patient, who had developed cardiac arrest during transport to our hospital and had been intubated after cardiopulmonary resuscitation for 5 minutes, was admitted to the emergency department on the 3 rd hour of her overdose drug intake. On the first physical examination, her general condition was poor, Glasgow coma scale score was 6 , heart rate was 40 beats per minute. She was intubated with $6.5 \mathrm{~mm}$ cuffed tube and respired with bag-valve-mask at a rate of 20 breaths/minute; oxygen saturation was 100\%; blood oxygen saturation level $\left(\mathrm{SpO}_{2}\right)$ was $90 \%$, the skin was cold, peripheral pulse could not be taken, capillary refill time was 5 seconds and blood pressure could not be measured. Her body weight was measured as $50 \mathrm{~kg}$ (50p). Blood gas analysis revealed the following results: $\mathrm{pH}: 7.29, \mathrm{PCO}_{2}: 40 \mathrm{mmHg}, \mathrm{PO}_{2}: 100$ $\mathrm{mmHg}, \mathrm{HCO}_{3}: 19 \mathrm{mmol} / \mathrm{L}$, and lactate: $3 \mathrm{mmol} / \mathrm{L}$. The results of complete blood count were as follows: leukocyte: 22800/mm33, hemoglobin: $12 \mathrm{~g} / \mathrm{dL}$, hematocrit: $37 \%$, and platelet count: $383000 / \mathrm{mm}^{3}$. On biochemical examination, the blood glucose level was $320 \mathrm{mg} / \mathrm{dL}$, creatinine - $1.1 \mathrm{mg} /$ $\mathrm{dL}$, aspartate aminotransferase - $191 \mathrm{U} / \mathrm{L}$, and the alanine aminotransferase level was $115 \mathrm{U} / \mathrm{L}$. Other results were within the normal range. Electrocardiography (ECG) showed first-degree atrioventricular block, PR interval was 0.21 second, QTc interval was 0.40 second. On bedside cardiac ultrasound, it was observed that cardiac contraction was poor and there was no pericardial or pleural fluid. Two $1000 \mathrm{~mL}$ boluses of isotonic saline were administered intravenously. 1 $\mathrm{mg}$ intravenous atropine was given three times. The patient was admitted to the pediatric intensive care unit and then was followed up on mechanical ventilatory support. Right femoral central venous catheter and right radial artery catheter were placed. Calcium gluconate (10\%) was administered at $0.6 \mathrm{~mL} / \mathrm{kg}$ intravenously and also glucagon ( $5 \mathrm{mg}$ ) was given subcutaneously (intravenous form was not available). Adrenalin $(0.1 \mathrm{mcg} / \mathrm{kg} / \mathrm{min})$ and noradrenalin $(0.1 \mathrm{mcg} / \mathrm{kg} /$ $\mathrm{min}$ ) infusions were initiated for the patient with hypotension. The rates of these infusions were gradually increased up to 2 $\mathrm{mcg} / \mathrm{kg} / \mathrm{min}$ to provide normal blood pressure. Insulin bolus of $1 \mathrm{U} / \mathrm{kg}$ was administered intravenously for severe hypotension; infusion was started as $0.5 \mathrm{U} / \mathrm{kg} /$ hour. Intravenous bolus of Calcium gluconate (10\%) was administered given at $0.6 \mathrm{~mL} /$ $\mathrm{kg}$ for hemodynamic instability. At the $60^{\text {th }}$ minute of the follow-up, despite intravenous fluid, calcium, insulin $(2 \mathrm{U} / \mathrm{kg} /$ hour) and high-dose vasopressors ( $2 \mathrm{mcg} / \mathrm{kg} / \mathrm{min}), 1.5 \mathrm{~mL} /$ $\mathrm{kg}$ infusion of 20\% lipid solution was given in 15 minutes due to resistant hypotension (Table 1). 8 The infusion rates of

\begin{tabular}{|c|c|c|c|c|c|c|c|c|c|}
\hline Time & $\begin{array}{l}\text { Pulse/ } \\
\text { min }\end{array}$ & $\begin{array}{l}\text { Blood } \\
\text { pressure } \\
\text { mmHg }\end{array}$ & $\begin{array}{l}\text { Blood } \\
\text { glucose } \\
\text { mg/dL }\end{array}$ & $\begin{array}{l}\text { Atropine } \\
\mathrm{mg}\end{array}$ & $\begin{array}{l}\text { Calcium } \\
\mathrm{mL} / \mathrm{kg} / \mathrm{hour}\end{array}$ & $\begin{array}{l}\text { Glucagon } \\
\text { Mg }\end{array}$ & $\begin{array}{l}\text { Insulin } \\
\text { U/kg/ } \\
\text { hour }\end{array}$ & $\begin{array}{l}\text { Adrenalin/ } \\
\text { Noradrenalin } \\
\mathrm{mcg} / \mathrm{kg} / \text { minute }\end{array}$ & $\begin{array}{l}\text { Lipid } \\
\mathrm{mL} / \\
\mathrm{kg}\end{array}$ \\
\hline 0. minute & 40 & - & 320 & $3 \times 1$ & $0.6^{*}$ & 5 & - & $0.1 / 0.1$ & \\
\hline \multirow[t]{2}{*}{ 40. minute } & 60 & $65 / 33$ & 273 & - & $0.6^{*}$ & - & $1 *$ & $1 / 1$ & \\
\hline & & & & & 0.5 & & 0.5 & & \\
\hline 2. hours & 82 & $92 / 58$ & 75 & - & 0.5 & - & 1.5 & $0.5 / 0.5$ & \\
\hline 6. hours & 60 & $94 / 56$ & 92 & & 0.5 & 5 & 1.5 & $0.1 / 0.2$ & \\
\hline 24. hours & 92 & $105 / 56$ & 90 & - & 0.5 & - & 1 & $-/ 0.1$ & \\
\hline 48. hours & 102 & $99 / 60$ & 88 & - & 0.1 & - & 0.5 & $-1-$ & \\
\hline 72. hours & 88 & $110 / 72$ & 90 & - & - & - & - & - & \\
\hline
\end{tabular}


adrenalin and noradrenalin were reduced rapidly due to good response to lipid therapy. The treatments and follow-up are given in Table 1. At the $48^{\text {th }}$ hour of the follow-up, as the vital signs, the results of blood gas and biochemistry tests, and ECG were normal, the patient was extubated. At the end of the $72^{\text {th }}$ hour, the heart rate was $88 /$ min (normal sinus rhythm), respiratory rate $-18 / \mathrm{min}$, blood pressure $-110 / 72$ $\mathrm{mmHg}$, and $\mathrm{SpO}_{2}$ was $99 \%$. Intravenous insulin infusion was discontinued. The patient was transferred to the ward on the $4^{\text {th }}$ day of the follow-up. She was discharged without sequelae on the $7^{\text {th }}$ day.

\section{Discussion}

$\mathrm{CCB}$ and $\mathrm{BB}$ intoxications can cause life-threatening conditions and they are treated with similar treatment principles. In the treatment of hypotension and cardiovascular collapse developed in overdoses of these drugs; fluid, vasopressor, inotrope and chronotrope agents are used. In the treatment of cardiovascular collapse, glucagon, calcium, and ILI treatment can be applied in cases refractory to intravenous fluid and catecholamines. 5 In our case, cardiopulmonary resuscitation was necessary following $\mathrm{CCB}$ and $\mathrm{BB}$ overdose; resistant hypotension did not ameliorate despite fluid, catecholamine, calcium, glucagon, and high-dose insulin treatment; the patient was discharged from the hospital without any sequelae after ILI treatment.

HIET has numerous positive effects in cardiogenic shock developed in CCB and BB intoxication. In animal models of propranolol and verapamil toxicity; it has been shown that survival rate increased and they ensured good hemodynamic stability when HIET was added compared to adrenalin and glucagon application alone. 5 Following HIET, the effect of the treatment begins between 15 and 60 minutes. 5 It is recommended that HIET should be commenced in cardiogenic shock and 0.5-2 U/ kg/hour maintenance infusion treatment is suggested following 0.5-1 U/kg load dose. 5 In our case, after a loading dose of $1 \mathrm{U} / \mathrm{kg}$ intravenous insulin, the infusion of $0.5 \mathrm{U} / \mathrm{kg} /$ hour was started and finally was increased up to $2 \mathrm{U} / \mathrm{kg} / \mathrm{hour}$. Some amount of dose could be reduced in vasopressors with insulin bolus administration for a short time. However, permanent hemodynamic stability could not be enabled with insulin administration.

ILI treatment is recommended as a rescue therapy in cases of severe overdose of lipophilic anesthetics largely and other drugs.9 Most studies carried out regarding ILI treatment were performed in CCB overdoses due to high lipophility. Five minutes after applying verapamil to 30 rats at toxic dose, Tebbutt et al.10 administered serum physiologic infusion to rats in control group over a five-minute period, and $12 \mathrm{~mL} / \mathrm{kg}$ of $20 \%$ lipid infusion to those in study group. They showed that survival rate increased in the lipid-administered group. In addition, lipid therapy doubled the average lethal dose of verapamil. The first lipid treatment was successfully applied in a case with intravenous bupivacaine toxicity in 2006.11 One hundred and three cases with single or multiple drug overdoses including local anesthetics with lipid and water solubility, antidepressant, antipsychotic, and cardiovascular drugs were retrospectively evaluated and it was reported that the positive effects of the treatment were not observed in only 16 cases (15.5\%). In 10 cases out of 12 with verapamil overdose and two cases with carvedilol overdose, the positive effects of lipid therapy were reported. 12 Graudins et al. 5 have reported that the positive effects of ILI applied as a rescue therapy in CCB and BB multiple drug overdoses were seen in some cases in an hour and a few hours in some patients. While the efficiency of ILI application was shown in $\mathrm{BB}$ and $\mathrm{CCB}$ overdoses, the recommended dose range is still controversial. The ILI dose according to the proposal of the American Regional Anesthesia Association in 2012 was intravenous bolus of $20 \%$ lipid emulsion, $1.5 \mathrm{~mL} / \mathrm{kg}$ of lean body mass, (can be repeated in persistent cardiovascular collapse) or it was in a continuous infusion way as 0.25-0.5 $\mathrm{mL} / \mathrm{kg} / \mathrm{min} .8$ In a retrospective study of nine adult patients, bolus application was compared with continuous infusion application. No significant difference was determined on the average arterial pressures. ${ }^{13}$ Despite $2 \mathrm{U} / \mathrm{kg} /$ hour insulin infusion in our case poisoned with carvedilol and verapamil in lipophilic characteristic 14,15, bolus ILE application was given at a dose of $1.5 \mathrm{~mL} / \mathrm{kg}$ in the 1 st hour of follow-up (20\% intralipid ${ }^{\circledR}$ ) and hemodynamic stability was ensured in half an hour. Vasopressor drugs could be decreased rapidly, ILI therapy was not required again. Potential side effects of ILI therapy were reported to be lipemic plasma, biochemistry laboratory abnormalities, hyperviscosity, pancreatitis, and noncardiogenic pulmonary edema. 5 No side effect was observed in our case following ILI therapy.

Poisonings of $\mathrm{CCB}$ and $\mathrm{BB}$ can be life-threatening. Recommended standard therapies can be inadequate in these poisonings. ILI treatment can be a life-saving treatment option in patients with CCB and BB intoxication who do not respond to classical supportive therapy and can develop lifethreatening cardiovascular collapse.

\section{Ethics}

Informed Consent: It was taken.

Peer-review: Externally peer-reviewed.

\section{Authorship Contributions}

Surgical and Medical Practices: Fulya Kamit Can, Concept: Fatih Durak, ikbal Durak, Design: Ayşe Berna Anıl, Data 
Collection or Processing: Neslihan Zengin, Kerem Yıldız, Analysis or Interpretation: Ayşe Berna Anıl, Fulya Kamit Can, Literature Search: Ikbal Durak, Neslihan Zengin, Kerem Yıldız, Writing: Fatih Durak, Ayşe Berna Anıl.

Conflict of Interest: No conflict of interest was declared by the authors.

Financial Disclosure: The authors declared that this study received no financial support.

\section{References}

1. Bronstein AC, Spyker DA, Cantilena LR, Jr., Rumack BH, Dart RC. 2011 Annual report of the American Association of Poison Control Centers' National Poison Data System (NPDS): 29th Annual Report. Clin Toxicol (Phila). 2012;50:911-1164.

2. Mowry JB, Spyker DA, Brooks DE, McMillan N, Schauben JL. 2014 Annual Report of the American Association of Poison Control Centers' National Poison Data System (NPDS): 32nd Annual Report. Clin Toxicol (Phila). 2015;53:962-1147.

3. Howarth DM, Dawson AH, Smith AJ, Buckley N, Whyte IM. Calcium channel blocking drug overdose: an Australian series. Hum Exp Toxicol. 1994;13:161-6.

4. Stellpflug SJ, Harris CR, Engebretsen KM, Cole JB, Holger JS. Intentional overdose with cardiac arrest treated with intravenous fat emulsion and high-dose insulin. Clin Toxicol (Phila). 2010;48:2279.

5. Graudins A, Lee HM, Druda D. Calcium channel antagonist and beta-blocker overdose: antidotes and adjunct therapies. Br J Clin Pharmacol. 2016;81:453-61.
6. Nelson RH, Prasad A, Lerman A, Miles JM. Myocardial uptake of circulating triglycerides in nondiabetic patients with heart disease. Diabetes. 2007;56:527-30.

7. Cave G, Harvey M. Intravenous lipid emulsion as antidote beyond local anesthetic toxicity: a systematic review. Acad Emerg Med. 2009;16:815-24

8. Neal JM, Bernards CM, Butterworth JFt, Di Gregorio G, Drasner K et al. ASRA practice advisory on local anesthetic systemic toxicity. Reg Anesth Pain Med. 2010;35:152-61.

9. Weinberg G. Lipid rescue resuscitation from local anaesthetic cardiac toxicity. Toxicol Rev. 2006;25:139-45.

10. Tebbutt S, Harvey M, Nicholson T, Cave G. Intralipid prolongs survival in a rat model of verapamil toxicity. Acad Emerg Med. 2006;13:134-9.

11. Rosenblatt MA, Abel M, Fischer GW, Itzkovich CJ, Eisenkraft JB. Successful use of a $20 \%$ lipid emulsion to resuscitate a patient after a presumed bupivacaine-related cardiac arrest. Anesthesiology. 2006;105:217-8

12. Cao D, Heard K, Foran M, Koyfman A. Intravenous lipid emulsion in the emergency department: a systematic review of recent literature. J Emerg Med. 2015;48:387-97.

13. Geib AJ, Liebelt E, Manini AF, Toxicology Investigators C. Clinical experience with intravenous lipid emulsion for drug-induced cardiovascular collapse. J Med Toxicol. 2012;8:10-4.

14. Reiter MJ. Cardiovascular drug class specificity: beta-blockers. Prog Cardiovasc Dis. 2004;47:11-33.

15. Montiel V, Gougnard T, Hantson P. Diltiazem poisoning treated with hyperinsulinemic euglycemia therapy and intravenous lipid emulsion. Eur J Emerg Med. 2011;18:121-3. 